\title{
Retraction Note: Impact of Teacher's Training on Interest and Academic Achievements of Students by Multiple Teaching Methods
}

ISSUE DATE

5 Feb. 2022

\section{ORIGINAL ARTICLE}

Hafeez, M. (2021). Impact of Teacher's Training on Interest and Academic Achievements of Students by Multiple Teaching Methods. Pedagogical Research, 6(3), em0102. https://doi.org/10.29333/pr/11088

It has brought to the attention of editorial office of Pedagogical Research that the original article, although first submission and the revision were both checked against plagiarism by the editors, was published in more than one journal. Submission of a manuscript for evaluation by the author to more than one journal at the same time is a serious violation of ethical principles of Pedagogical Research. Therefore, the original article is retracted by the editors. 